
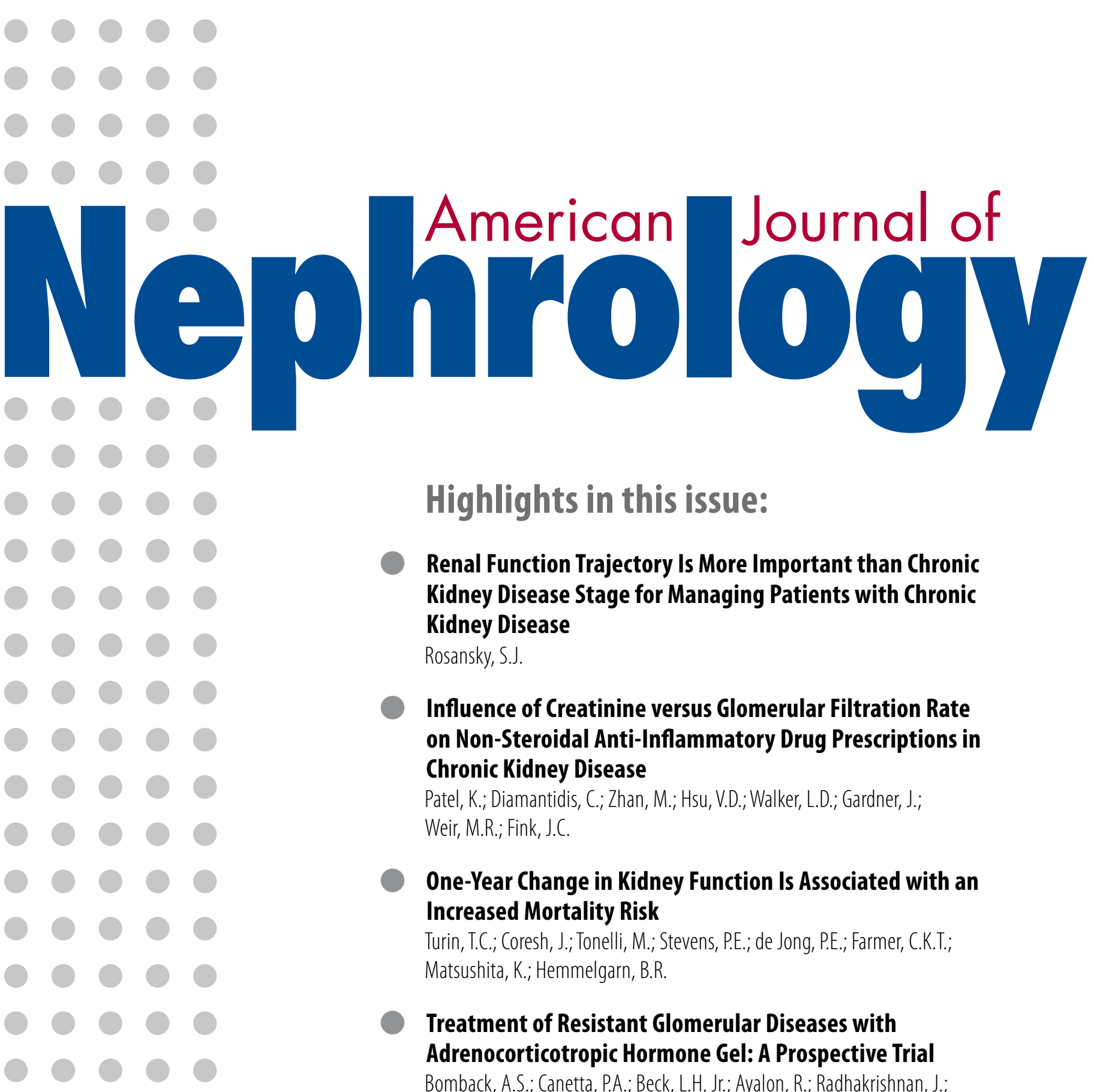

\title{
Highlights in this issue:
}

Renal Function Trajectory Is More Important than Chronic Kidney Disease Stage for Managing Patients with Chronic Kidney Disease

Rosansky, S.J.

Influence of Creatinine versus Glomerular Filtration Rate on Non-Steroidal Anti-Inflammatory Drug Prescriptions in Chronic Kidney Disease

Patel, K.; Diamantidis, C.; Zhan, M.; Hsu, V.D.; Walker, L.D.; Gardner, J.; Weir, M.R.; Fink, J.C.

One-Year Change in Kidney Function Is Associated with an Increased Mortality Risk

Turin, T.C.; Coresh, J.; Tonelli, M.; Stevens, P.E.; de Jong, P.E.; Farmer, C.K.T.; Matsushita, K.; Hemmelgarn, B.R.

Treatment of Resistant Glomerular Diseases with Adrenocorticotropic Hormone Gel: A Prospective Trial Bomback, A.S.; Canetta, P.A.; Beck, L.H. Jr.; Ayalon, R.; Radhakrishnan, J.; Appel, G.B. 


\title{
Bridging the gaps between medicine, ethics, philosophy and religion
}

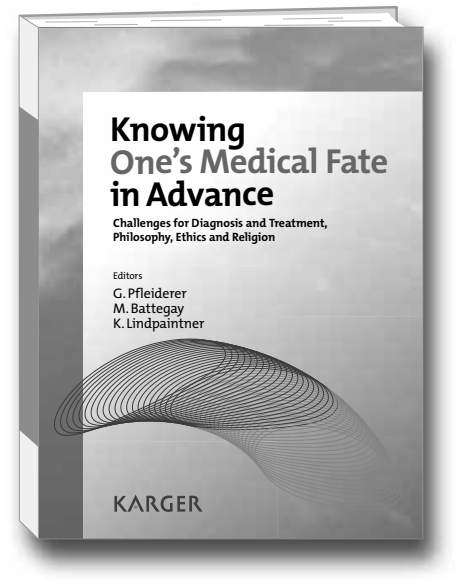

\section{Knowing One's Medical Fate in Advance}

\section{Challenges for Diagnosis and Treatment, Philosophy, Ethics and Religion}

\author{
Editors \\ Georg Pfleiderer \\ Manuel Battegay \\ Klaus Lindpaintner
}

Modern medicine is now in a position to make advanced prognoses that chart the entire course of illness and recovery. Paradoxically, this is coupled with a new dimension of uncertainty for the patient, i.e. coming to terms with discovering they have an increased risk of a particular disease and deciding what appropriate steps to take. In this publication, renowned experts in their fields discuss these issues.

The certainty and uncertainty of one's fate are discussed from both methodological and epidemiological perspectives, using examples of diseases for which treatment and prognosis have dramatically changed. Despite profound insights into the human genome, personalized genetically tailored medicine still lies in the future. Religious, spiritual and philosophical dimensions are discussed, as are the ways in which they may help people cope with these new insights into their future, e.g. the promise of an afterlife.

This publication aims to bridge the different fields dealing with this area by addressing the challenges faced and encouraging dialogue. It will be of interest to all readers who deal with ethical problems of prognosis, particularly in medicine, as well as to theologians and sociologists.

\section{Contents}

Introduction: Pfleiderer, G.; Battegay, M.; Lindpaintner, $K$.

\section{Medical Perspectives}

- Evolving Therapy and Prognosis in HIV - How Knowing One's Medical Fate in Advance Can Change Dramatically: Battegay, $\boldsymbol{M}$.

- Related to Human Cognition: Is Personalization Feasible and Desirable?: Papassotiropoulos, $A$.

\section{Ethical and Juridical Perspectives}

- Ethical Decision-Making on Genetic Diagnosis Facing the Challenges of Knowing One's Medical Fate in Advance: Brahier, G.

- Mastering Familial Genetic Knowledge: Shared or Secret? Issues of DecisionMaking in Predictive Genetic Testing: Brüninghaus, A.; Porz, $R$.

- Predictive Medicine - Changes in Our View of Ourselves and Others: Birnbacher, $\boldsymbol{D}$.

- Current Challenges for the Law: Disclosure Dilemmas in Predictive Medicine: Dörr, B.S.
Religious Perspectives

- Fate and Judaism - Philosophical and Clinical Aspects: Gesundheit, B.

- Modern Medicine and My Future Life: A Christian-Theological Perspective: Pfleiderer, $G$.

- Karma, Contingency, and the 'Point of No Return': Predictive Medicine and Buddhist Perspectives: Schlieter, J.

\section{Author Index}

Subject Index

\section{KARGER}

www.karger.com/medical-fate

Knowing One's Medical Fate in Advance Challenges for Diagnosis and Treatment, Philosophy, Ethics and Religion

Editors: Pfleiderer, G.; Battegay, M. (Basel); Lindpaintner, K. (Newark, Del.)

VI +122 p., 4 fig., 2 in color, hard cover, 2012 CHF 59.- / EUR 49.- / USD 69.00

Prices subject to change

EUR price for Germany, USD price for USA only

ISBN 978-3-8055-9649-7

e-ISBN 978-3-8055-9650-3

\section{Please send: _ c copy/ies}

Postage and handling free with prepayment

E

Payment:

Please charge to my credit card

- $\square$ American Express $\square$ Diners

ᄂ $\square$ MasterCard $\square$ Visa

- Card No.

(

Exp. date:

C CVV/CVC

( 3 digits in the signature field on the back of Visa and MasterCard)

$\square$ Check enclosed $\quad \square$ Please bill me

Orders may be placed with any bookshop, subscription agency, directly with the publisher or through a Karger distributor.
Fax: +41 613061234

S. Karger AG, P.O. Box, CH-4009 Basel (Switzerland) E-Mail orders@karger.ch, www.karger.com

Name/Address: 


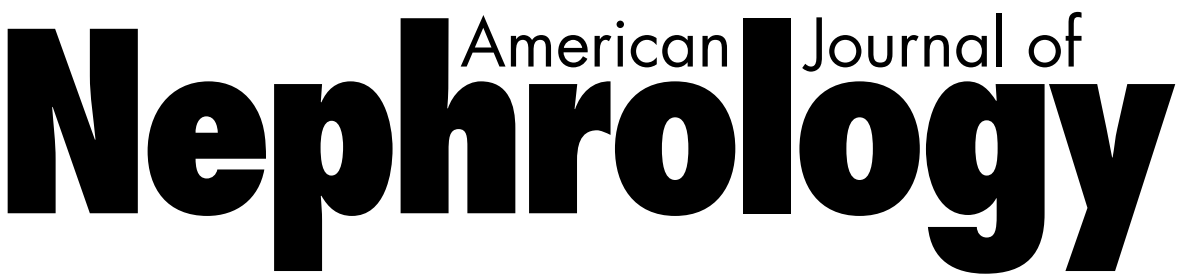

Founded 1981 and edited until 2002 by S.G. Massry

\section{Editor-in-Chief}

G.L. Bakris, Chicago, Ill.

\section{Associate Editors}

R. Agarwal, Indianapolis, Ind.

R.J. Glassock, Los Angeles, Calif.

B. Palmer, Dallas, Tex.

S. Sprague, Evanston, Ill.

M.R. Weir, Baltimore, Md.

\section{Section Editors}

K.C. Abbott, Washington, D.C.

E.A. Ross, Gainesville, Fla.

\section{Administrative Assistant}

B. Brisky, Chicago, Ill.

\section{Editorial Board}

C.K. Abrass, Seattle, Wash.

F. Ali, Chicago, Ill.

J.R. Asplin, Chicago, Ill.

J. Arruda, Chicago, Ill.

P. August, New York, N.Y.

A.S. Awad, Hershey, Pa.

M. Banks, Denver, Colo.

V.K. Bansal, Maywood, Ill.

E. Benedetti, Chicago, Ill.

P. Blake, London, Ontario

M. Braun, Houston, Tex.

E. Brooks, Chicago, Ill.

M. Burnier, Lausanne

D. Capone, Naples

D.F. Catanzaro, New York, N.Y.

J. Cockroft, Cardiff

M. Cooper, Melbourne

R. Danziger, Chicago, Ill.
J. Daugirdas, Chicago, Ill.

S. D'Souza, London, Ontario

S. El-Dahr, New Orleans, La.

L. Ferder, Ponce, P.R.

B.I. Freedman, Winston-Salem, N.C.

D. Grekas, Thessaloniki

B. Hoppe, Cologne

R. Johnson, Aurora, Colo.

M. Josephson, Chicago, Ill.

K. Kalantar-Zadeh, Torrance, Calif.

J. Kopp, Bethesda, Md.

C.B. Langman, Chicago, Ill.

D. Leehey, Hines, Ill.

S.L. Linas, Denver, Colo.

M.S. Lipkowitz, New York, N.Y.

N. Litbarg, Chicago, Ill.

S. Moe, Indianapolis, Ind.

M. Nangaku, Tokyo

S.B. Nicholas, Los Angeles, Calif.

M.D. Okusa, Charlottesville, Va.

A.J. Peixoto, West Haven, Conn.

A. Portale, San Francisco, Calif.

A. Pozzi, Nashville, Tenn.

W. Proesmans, Leuven

M. Rahman, Cleveland, Ohio

N.M. Rajamannan, Chicago, Ill.

G. Remuzzi, Bergamo

M. Rudnick, Philadelphia, Pa.

R. Sam, San Francisco, Calif.

P. Sarafidis, Thessaloniki

J. Sedor, Cleveland, Ohio

K.C. Siamopoulos, Ioannina

A.K. Singh, Chicago, Ill.

D. Sirivongs, Khon Kaen

H. Suzuki, Saitama

V. Thongboonkerd, Bangkok

C. Tikellis, Melbourne

G. Tsirpanlis, Athens

K. Tuttle, Spokane, Wash.

A.Y.-M. Wang, Hong Kong

A. Whaley-Connell, Columbia, Mo.

J. Yee, Detroit, Mich.
Printed in Switzerland on acid-free and non-aging paper (ISO 9706) by Reinhardt Druck, Basel
Appearance:

2 volumes per year (12 issues) 


\section{Nephrology}

\section{Submission}

The 'American Journal of Nephrology' only accepts online submissions to:

http://mc.manuscriptcentral.com/ajn

All further technical instructions can be found there.

\section{Conditions}

The journal will not publish articles which have been previously reported at any length or articles being considered for publication elsewhere. The authors must include a statement to this effect in their cover letter. If publication of the data in any form has occurred or is being contemplated, a copy of such publication should be included with the submitted manuscript. Failure to comply with this directive or discovery of any manuscript text, figure(s), or table(s) duplication will result in immediate retraction of the manuscript and/or article and the authors will not be allowed to submit any future manuscripts to this journal for a period of 3 years. Submission of an article for publication implies the transfer of the copyright from the author to the publisher upon acceptance. It is the author's responsibility to obtain permission to reproduce illustrations, tables, etc. from other publications. The manuscript should be written in English and the editors reserve the right to make appropriate corrections in grammar and style. Accepted papers become the permanent property of the 'American Journal of Nephrology' and may not be reproduced by any means, in whole or in part, without the written consent of the publisher. Information concerning financial disclosures (i.e. grants, funding, support, etc.) should be placed at the foot of the title page.

\section{Types of Article for Acceptance}

(1) Original Reports: Representing full sets of completed experiments in the areas of either clinical or basic research that answer a given question. Max. 3,000 words, incl. figures, tables. Maximum 25 references.

a) Transplantation: Manuscripts under this section include both basic and translational topics. Original experimental data are preferred; however, other content will be considered. Guidelines for this category are similar to the other original reports.

b) Patient-oriented, translational research.

c) Laboratory investigation

(2) In-Depth Topic Reviews: Covering a timely topic by experts in the field. Max. 4,500 words, incl. figures, tables. Maximum 60 references.

(3) Nephrology Grand Rounds: We welcome submissions to this section which is designed as a forum for nephrology trainees to discuss disease presentations or cases deserving exceptional merit. The section, however, is intended to extend far beyond the scope of a typical case report. Specifically, we seek case series (e.g. 5 or 6 cases) representing either similar illnesseses or noteworthy unusual manifestations. It is expected that papers will incorporate not only a thorough but also a critical review of the literature. The intent is for senior co-authorships and active involvement on their parts. Submissions are limited to 2,500 words, 1 figure, 1 table and 20 references.

(4) Hot Topics in Nephrology: A Debate (by invitation only): These will be debate forums of unsolved and important clinical issues in nephrology.
There will be a pro and con position and each will consist of 1,500 words with a maximum of 7 key references. The topic will be determined by the editorial board but any proposals are welcomed.

(5) Invited Editorials: The Editor(s) will invite editorials on specifically selected articles. The editorial will have a maximum of 1,000 words and up to 10 references (one of which should be the paper being reviewed). Also, a maximum of one figure or table is allowed.

\section{Conflicts of Interest}

Authors are required to disclose any sponsorship or funding arrangements relating to their research and all authors should disclose any possible conflicts of interest. Conflict of interest statements will be published at the end of the article.

\section{Ethics}

Published research must comply with the guidelines for human studies and animal welfare regulations. Authors should state that subjects have given their informed consent and that the study protocol has been approved by the institute's committee on human research. Further, they should also state that animal experiments conform to institutional standards.

\section{Plagiarism Policy}

Plagiarism is misrepresenting somebody else's published intellectual work-product as your own (Note, this definition excludes 'self-plagiarism'). In short, it is a misuse of source material. Whether intentional or unintentional, plagiarism is a serious violation of the 'American Journal of Nephrology' policy. Periodically, manuscripts are screened for plagiarism and if your manuscript is found to be consistent with what the Editors define $e^{*}$ as plagiarism prior to review of the manuscript then

1) it will be rejected without review and the author(s) notified as such with a chance for rebuttal.

If a manuscript is found to contain evidence of plagiarism after acceptance and/or publication then:

1) the author(s) will be notified, as in the previous situation, and offered a chance for rebuttal.

If the rebuttal arguments are not found to be satisfactory, as judged by the Editors, the manuscript will be rejected and the author sanctioned from publishing additional papers in the Journal for a period to be determined by the Editorial Board. The period of sanction imposed is dependent on the magnitude of plagiarism with a minimum sanction of one year. If a manuscript already published in the Journal is found to exhibit evidence of plagiarism as defined by the Editors ${ }^{\star}$, then we will request a retraction.

${ }^{\star}$ Definition of plagiarism - a $25 \%$ similarity in the Results or Discussion that exactly reproduces another paper.

\section{Arrangement}

Title page: The first page of each paper should indicate the title, the authors' names, the institute where the work was conducted, a short title for use as running head, conflict of interest statement, key words, and word count. Manuscripts are to be double-spaced and formatted using the same font, size 12 throughout text and references.
Full address: The exact postal address of the corresponding author complete with postal code must be given at the bottom of the title page. Please also supply phone and fax numbers, as well as e-mail address.

Key words: Please supply 3-10 key words in English that reflect the content of the paper.

Abstract: Each paper needs an abstract of up to 250 words. It should be structured as follows:

Background/Aims: What is the major problem that prompted the study?

Methods: How was the study performed?

Results: Most important findings?

Conclusion: Most important conclusion?

\section{Footnotes: Avoid footnotes.}

Tables and illustrations: Tables and illustrations (both numbered in Arabic numerals) should be prepared on separate pages. Tables require a heading and figures a legend, also prepared on a separate page. Electronically submitted b/w half-tone and color illustrations must have a final resolution of $300 \mathrm{dpi}$ after scaling, line drawings one of 800-1,200 dpi. Average table $=250$ words

The maximum size of all uploaded files is $40 \mathrm{MB}$.

\section{Color Illustrations}

Online edition: Color illustrations are reproduced free of charge. In the print version, the illustrations are reproduced in black and white. Please avoid referring to the colors in the text and figure legends. Print edition: Up to 6 color illustrations per page can be integrated within the text at CHF 800.- per page.

\section{References}

In the text identify references by Arabic numerals [in square brackets]. Material submitted for publication but not yet accepted should be noted as 'unpublished data' and not be included in the reference list. The list of references should include only those publications which are cited in the text. Do not alphabetize; number references in the order in which they are first mentioned in the text. The surnames of the authors followed by initials should be given. There should be no punctuation other than a comma to separate the authors. Preferably, cite all authors. Abbreviate journal names according to the Index Medicus system. Also see International Committee of Medical Journal Editors: Uniform requirements for manuscripts submitted to biomedical journals (www.icmje.org).

Examples

(a) Papers published in periodicals: Chatel J-M, Bernard $\mathrm{H}$, Orson FM: Isolation and characterization of two complete Ara h 2 isoforms cDNA. Int Arch Allergy Immunol 2003;131:14-18.

(b) Papers published only with DOI numbers:

Theoharides TC, Boucher W, Spear K: Serum interleukin-6 reflects disease severity and osteoporosis in mastocytosis patients. Int Arch Allergy Immunol DOI: $10.1159 / 000063858$

(c) Monographs: Matthews DE, Farewell VT: Using and Understanding Medical Statistics, ed 3, revised. Basel, Karger, 1996.

(d) Edited books: DuBois RN: Cyclooxygenase-2 and colorectal cancer; in Dannenberg AJ, Dubois RN (eds): COX-2. Prog Exp Tum Res. Basel, Karger, 2003, vol 37, pp 124-137.

\section{KARGER}

Fax +41 613061234 E-Mail karger@karger.ch www.karger.com 
Reference Management Software: Use of EndNote is recommended for easy management and formatting of citations and reference lists.

\section{Digital Object Identifier (DOI)}

S. Karger Publishers supports DOIs as unique identifiers for articles. A DOI number will be printed on the title page of each article. DOIs can be useful in the future for identifying and citing articles published online without volume or issue information. More information can be found at www.doi.org.

\section{Supplementary Material}

Supplementary material is restricted to additional data that are not necessary for the scientific integrity and conclusions of the paper. Please note that all supplementary files will undergo editorial review and should be submitted together with the original manuscript. The Editors reserve the right to limit the scope and length of the supplementary material. Supplementary material must meet production quality standards for Web publication without the need for any modification or editing. In general, supplementary files should not exceed $10 \mathrm{MB}$ in size. All figures and tables should have titles and legends and all files should be supplied separately and named clearly. Acceptable files and formats are: Word or PDF files, Excel spreadsheets (only if the data cannot be converted properly to a PDF file), and video files (.mov, .avi, .mpeg)
Author's Choice ${ }^{\mathrm{TM}}$

Karger's Author's Choice ${ }^{\mathrm{TM}}$ service broadens the reach of your article and gives all users worldwide free and full access for reading, downloading and printing at www.karger.com. The option is available for a onetime fee of CHF 3000.-, which is a permissible cost in grant allocation. More information can be found at www.karger.com/authors_choice.

\section{NIH-Funded Research}

The U.S. National Institutes of Health (NIH) mandates under the NIH Public Access Policy that final, peer-reviewed manuscripts appear in its digital database within 12 months of the official publication date. As a service to authors, Karger submits the final version of your article on your behalf to PubMed Central. For those selecting our premium Author's Choice $^{\mathrm{TM}}$ service, we will send your article immediately upon publishing, accelerating the accessibility of your work without the usual embargo. More details on NIH's Public Access Policy is available at http:// publicaccess.nih.gov/FAQ.htm\#a1

\section{Self-Archiving}

Karger permits authors to archive their pre-prints (i.e. pre-refereeing) or post-prints (i.e. final draft post-refereeing) on their personal or institution's servers, provided the following conditions are met: Articles may not be used for commercial purposes, must be linked to the publisher's version, and must acknowledge the publisher's copyright. Authors selecting Karger's Author's Choice ${ }^{\mathrm{TM}}$ feature, however, are also permitted to archive the final, published version of their article, which includes copyediting and design improvements as well as citation links.

\section{Page Charges}

Original Reports exceeding the first 3 printed pages which are free will cost CHF 325.- per extra page. Review papers exceeding the first 6 printed pages which are free will cost CHF 325.- per extra page.

\section{Proofs}

Unless indicated otherwise, proofs are sent to the corresponding author and should be returned with the least possible delay. Alterations made in proofs, other than the correction of printer's errors, as well as corrections after approval to publication, are charged to the author.

\section{Reprints}

Order forms and a price list are sent with the proofs. Orders submitted after the issue is printed are subject to considerably higher prices.

\section{'A collection of extraordinary essays'}

\section{GOTTFRIED SCHATZ}

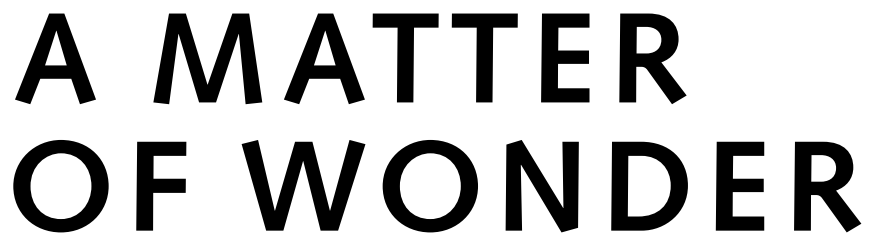

What Biology Reveals about Us, Our World, and Our Dreams

Where do we come from? Is our destiny determined by the genes we inherit? In this book Gottfried Schatz, the world-renowned biochemist and co-discoverer of mitochondrial DNA, gives lucid - albeit often surprising - answers to universal questions and takes the reader on a fascinating journey of discovery across the boundaries of scientific disciplines. With passion and a keen sense of wonder he draws on philosophy, cultural history and art to formulate his reflections on the mysteries of life. His essays will appeal not only to scientists but to all inquisitive minds, regardless of educational and professional background.

\section{KARGER}

S. Karger AG, P.O. Box $\mathrm{CH}-4009$ Basel

(Switzerland)
Fax +41613061234 E-Mail orders@karger.ch www.karger.com

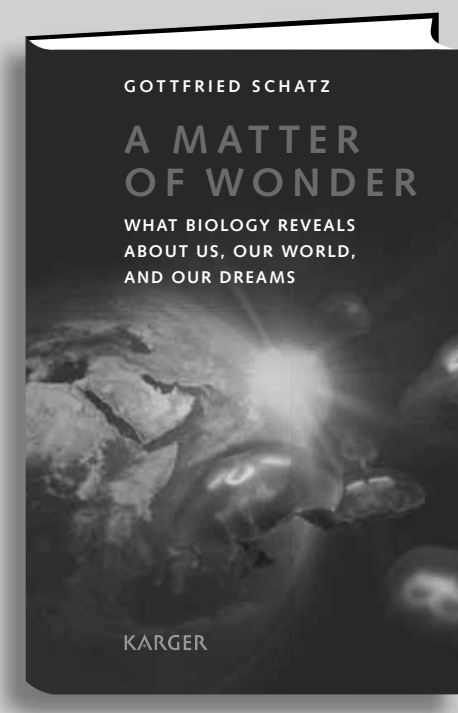

G. Schatz (Basei)

A Matter of Wonder

What Biology Reveals about Us,

Our World, and Our Dreams

Translated by A. Shields

XII + 190 p., 2 color fig., hard cover, 2011

CHF 29.-/ EUR 21.50/USD 29.00

ISBN 978-3-8055-9744-9

More information and sample essays at www.karger.com/schatz

\section{KARGER}

Fax +4161306 1234

E-Mail karger@karger.ch

www.karger.com
(C) 2012 S. Karger AG, Basel

The Guidelines for Authors are available at:

www.karger.com/ajn_Guidelines 


\section{Nephrology}

ISSN Print Edition: 0250-8095

ISSN Online Edition: 1421-9670

Journal Homepage: www.karger.com/ajn

Publication Data: 'American Journal of Nephrology' is published 12 times a year. Volumes 35 and 36, each

Copyright: (c) 2012 S. Karger AG, Basel (Switzerland). All rights reserved. No part of this publication may be translated into other languages, reproduced or utilized in any form or by any means, electronic or mechanical, including photocopying, recording, microcopying, or out permission in writing from the publisher or, in the case of photocopying, direct payment of a specified fee

Disclaimer: The statements, opinions and data contained in this publication are solely those of the individual authors and contributors and not of the publisher and the editor(s). The appearance of advertisements in the journal is not a warranty, endorsement, or approval of the products or services advertised or of their effectiveness, quality or safety. The publisher and the editor(s) disclaim responsibility for any injury to persons or property resulting from any ideas, methods, instructions or products referred to in the content or advertisements. with 6 issues appear in 2012 . by any information storage and retrieval system, withto the Copyright Clearance Center.
Subscription Rates: Subscriptions run for a full calendar year. Prices are given per year. Personal subscription:

Print or Online

CHF 944.-

EUR 756.-

USD 917.00

Print+Online combined CHF 1040.-

EUR 832.-

USD 1011.00

postage and handling (added to print and print+online)

CHF 81.60 Europe, CHF 120.00 Overseas

EUR 62.40

USD 112.80

Institutional subscription

Print or Online

Print+Online combined

CHF 4722.

EUR 3778.-

CHF 5194.

USD 4584.00

postage and handling (added to print and print+online)

CHF 102.- Europe, CHF 150.- Overseas

EUR 78.-

USD 141.00

Airmail surcharge: CHF 102.- / USD 96.00
Back Volumes and Single Issues: Information on availability and prices of single print issues and prin or electronic back volumes can be obtained from Customer Service at service@karger.ch.

Bibliographic Indices: This journal is regularly listed in bibliographic services, including Current Contents ${ }^{\circledR}$ and PubMed/MEDLINE.

Photocopying: This journal has been registered with the Copyright Clearance Center (CCC), as indicated by the code appearing on the first page of each article. For readers in the US, this code signals consent for copying sonal or internal use of specific clients, provided that the stated fee is paid per copy directly to

Copyright Clearance Center Inc

222 Rosewood Drive

Danvers, MA 01923 (USA)

A copy of the first page of the article must accompany payment. Consent does not extend to copying for general distribution, for promotion, for creating new works, or for resale. In these cases, specific written permission must be obtained from the copyright owner,

S. Karger AG, P.O. Box

CH-4009 Basel (Switzerland). of articles for personal or internal use, or for the per-
Subscription Orders:

Orders can be placed at agencies, bookstores, directly with the Publisher

\section{S. Karger AG}

Medical and Scientific Publishers

P.O. Box

CH-4009 Basel

Switzerland

(for courier services only:

Allschwilerstrasse 10

f: +41613061234

e: karger@karger.ch

w: www.karger.com
$\mathrm{CH}-4055$ Basel)

t: +41613061111 or further Karger offices

or representatives:

Germany

S. Karger GmbH

Postfach

79095 Freiburg

Deutschland

(Hausadresse: Wilhelmstrasse 20A

79098 Freiburg)

t: +49761452070

f: +497614520714

e: information@karger.de

w: www.karger.de

Japan

Karger Japan, Inc.

Shiba Daimon Asahi Bldg. 2F

1-2-23 Shiba Daimon

Minato-ku

Tokyo 105-0012

Japan

t: +81364356242

f: +81364356244

e: publisher@karger.jp

w: www.karger.jp
Change of Address:

Both old and new address should be sent

to the subscription source.
USA

S. Karger Publishers, Inc.

26 West Avon Road

P.O. Box 529

Unionville, CT 06085

USA

Toll free: +18008285479

t: $\quad+18606757834$

f: +18606757302

e: karger@snet.net

France

Librairie Médi-Sciences Sar

36, bd de Latour-Maubourg

75007 Paris

France

$\mathrm{t}:+33(0) 145514258$

f. $+33(0) 145560780$

e: librairie@medi-sciences.fr

Gulf Council Countries, Iran,

Middle East, North Africa, Turkey

Trans Middle East International

Distribution Co. Ltd.

KaSha

134 Queen Rania Al Abdullah Street

Jordan Trade Center Bldg. 3rd Floor

P.O. Box 2376

Amman 11953

Jordan

$\mathrm{t}:$ +962 65153467

f: +96265153472

e: info@kasha.cc

w: www.KaShaoonline.com w: www.medi-sciences.fr
South East Asia, China and Taiwan

Karger Regional Office (Malaysia)

CEO Suite Kuala Lumpur

Quill 7, 27th Floor

Jalan Stesen Sentral 5

KL Sentral

Kuala Lumpur 50470

Malaysia

t: +60327766803

f: +60327766999

e: service@karger.cn; r.chew@karger.cn

\section{Karger China}

10th Floor, Twin Towers (East)

B12 Jianguomenwai Avenue

Beijing 100022

China

t: +861051235033

f: +861051235122

e: service@karger.cn; r.chew@karger.cn

w: www.karger.cn

India, Bangladesh, Sri Lanka

Medscience India

Plot No. 17, Yusuf Sarai Market

B.L. Glass Building, 2nd Floor

Sri Aurobindo Marg

New Delhi 110016

India

t: +911146029633

f: +911146029634

c: +919891052128

e: medsci.india@gmail.com

\section{KARGER}

Fax +41 613061234

E-Mail karger@karger.ch

www.karger.com
(C) 2012 S. Karger AG, Basel

The Journal Home Page is available at:

www.karger.com/ajn 


\section{Contents}

See the journal website for contents

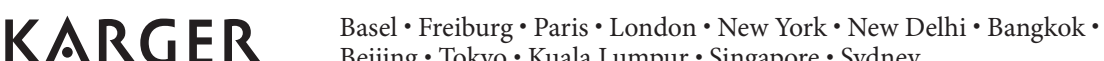
Beijing $\cdot$ Tokyo $\cdot$ Kuala Lumpur $\cdot$ Singapore $\cdot$ Sydney 
Nephingicologogy

Managing Editor

G. Bakris, Chicago, III.

Associate Editors

R. Agarwal, Indianapolis, Ind.

R.J. Glassock, Laguna Niguel, Calif.

B. Palmer, Dallas, Tex.

S. Sprague, Evanston, III.

M. Weir, Baltimore, Md.
The American Journal of Nephrology is a peer-reviewed journal which mainly focuses on timely topics in basic science with possible clinical applicability. Papers are divided into several sections, including:

- Original reports, representing full sets of completed experiments that answer a given question

- In-depth topic reviews on a given topic which may be invited or submitted by a group or individual for review

- 'Kidney and beyond' publishes selected review articles on recently discovered molecules or molecular pathways that have the potential to regulate structural and functional aspects of inflammatory, systemic, metabolic or neoplastic renal diseases.

Responding to the ever increasing pace in research, the American Journal of Nephrology adheres to a very tight publication schedule: papers are published online first, and their printed version is included in the next issue.

\section{Selected contributions}

Acute Kidney Injury following Cardiac Surgery: Role of Perioperative Blood

Pressure Control: Weir, M.R. (Baltimore, Md.); Aronson, S. (Durham, N.C.); Avery, E.G.

(Cleveland, Ohio); Pollack, C.V., Jr. (Philadelphia, Pa.)

Effect of Bardoxolone Methyl on Kidney Function in Patients with T2D and Stage 3b-4 (KD: Pergola, P.E. (San Antonio, Tex.); Krauth, M.; Huff, J.W.; Ferguson, D.A.; Ruiz, S.; Meyer, C.J. (Irving, Tex.); Warnock, D.G. (Birmingham, Ala.)

Statins for the Prevention of Contrast-Induced Nephropathy: A Systematic Review and Meta-Analysis: Zhang, T.; Shen, L.-H.; Hu, L.-H.; He, B. (Shanghai)

Soluble P-Selectin Levels Are Associated with Cardiovascular Mortality and Sudden Cardiac Death in Male Dialysis Patients: Scialla, J.J. (Baltimore, Md.); Plantinga, L.C. (San Francisco, Calif.); Kao, W.H.L.; Jaar, B. (Baltimore, Md.); Powe, N.R. (San Francisco, Calif.); Parekh, R.S. (Baltimore, Md./Toronto, Ont.)

Nongenomic Effects of Aldosterone on Renal Protein Expressions of pEGFR and pERK1/2 in Rat Kidney: Sinphitukkul, K.; Eiam-Ong, S.; Manotham, K.; Eiam-Ong, S. (Bangkok)

Haemodiafiltration versus High-Flux Haemodialysis: Effects on Phosphate Control and Erythropoietin Response: Oates, T.; Pinney, J.H.; Davenport, A. (London)

Sevoflurane Protects against Acute Kidney Injury in a Small-Size Liver

Transplantation Model: Kong, H.Y.; Zhu, S.M.; Wang, L.Q.; He, Y.; Xie, H.Y.; Zheng, S.S. (Hangzhou)

Renal Replacement Therapy for Prevention of Contrast-Induced Acute Kidney Injury: A Meta-Analysis of Randomized Controlled Trials: Song, K.; Jiang, S.; Shi, Y.; Shen, H.; Shi, X.; Jing, D. (Suzhou)
More information at

\section{www.karger.com/ajn}

- Pay-per-View and Subscriber Access to Full Text

- Full Table of Contents

- Full Editorial Board

- Free Abstracts and Selected Articles

- Online Sample Issue

- Submission / Guidelines for Authors

- Subscription Details

- Free Alert Service

- Online Library Recommendation

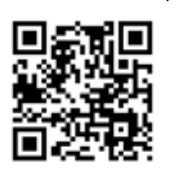

American Journal of Nephrology

2012: Volumes 35, 36

6 issues per volume

Language: English

ISSN 0250-8095 (print)

ISSN 1421-9670 (online) 


\section{In-Depth Topic Reviews}

1 Renal Function Trajectory Is More Important than Chronic Kidney Disease Stage for Managing Patients with Chronic Kidney Disease

Rosansky, S.J. (Columbia, S.C.)

97 Understanding Hypernatremia

Sam, R. (San Francisco, Calif.); Feizi, I. (Ardabil)

Original Report: Laboratory Investigation

34 Genistein Attenuates Advanced Glycation End Product-Induced Expression of Fibronectin and Connective Tissue Growth Factor

Tong, M.; Wang, Y.; Wang, Y.; Chen, H.; Wang, C.; Yang, L. (Hangzhou); Axelsson, J.; Lindholm, B. (Stockholm)

Original Reports: Patient-Oriented, Translational Research

11 Early Arterial Stiffness and Inflammatory Bio-Markers in Normotensive Polycystic Kidney Disease Patients Kocyigit, I.; Kaya, M.G.; Orscelik, O. (Kayseri); Kaya, C. (Samsun); Akpek, M. (Kayseri); Zengin, H. (Samsun); Sipahioglu, M.H.; Unal, A. (Kayseri); Yilmaz, M.I. (Ankara); Tokgoz, B.; Oymak, O. (Kayseri); Axelsson, J. (Stockholm)

19 Influence of Creatinine versus Glomerular Filtration Rate on Non-Steroidal Anti-Inflammatory Drug Prescriptions in Chronic Kidney Disease Patel, K.; Diamantidis, C.; Zhan, M.; Hsu, V.D.; Walker, L.D.; Gardner, J.; Weir, M.R.; Fink, J.C. (Baltimore, Md.)

27 A Comparison of Herpes Zoster Incidence across the Spectrum of Chronic Kidney Disease, Dialysis and Transplantation

Lin, S.-Y.; Liu, J.-H.; Lin, C.-L.; Tsai, I-J.; Chen, P.-C.; Chung, C.-J.; Liu, Y.-L.; Wang, I-K.; Lin, H.-H.; Huang, C.-C. (Taichung)
41 One-Year Change in Kidney Function Is Associated with an Increased Mortality Risk

Turin, T.C. (Calgary, Alta.); Coresh, J. (Baltimore, Md.); Tonelli, M. (Edmonton, Alta.); Stevens, P.E. (Canterbury); de Jong, P.E. (Groningen); Farmer, C.K.T. (Canterbury); Matsushita, K. (Baltimore, Md.); Hemmelgarn, B.R. (Calgary, Alta.)

50 Iron Sucrose Impairs Phagocytic Function and Promotes Apoptosis in Polymorphonuclear Leukocytes Ichii, H.; Masuda, Y.; Hassanzadeh, T.; Saffarian, M.; Gollapudi, S.; Vaziri, N.D. (Irvine, Calif.)

58 Treatment of Resistant Glomerular Diseases with Adrenocorticotropic Hormone Gel: A Prospective Trial Bomback, A.S.; Canetta, P.A. (New York, N.Y.); Beck, L.H. Jr.; Ayalon, R. (Boston, Mass.); Radhakrishnan, J.; Appel, G.B. (New York, N.Y.)

68 Phylloquinone and Vitamin D Status: Associations with Incident Chronic Kidney Disease in the Framingham Offspring Cohort

O’Seaghdha, C.M. (Framingham, Mass./Boston, Mass.); Hwang, S.-J. (Framingham, Mass.); Holden, R. (Kingston, Ont.); Booth, S.L. (Boston, Mass.); Fox, C.S. (Framingham, Mass./ Boston, Mass.)

78 Idiopathic Membranous Nephropathy: Clinical and Histologic Prognostic Features and Treatment Patterns over Time at a Tertiary Referral Center Sprangers, B.; Bomback, A.S.; Cohen, S.D.; Radhakrishnan, J.; Valeri, A.; Markowitz, G.S; D’Agati, V.; Appel, G.B. (New York)

90 Association of Race with Cumulative Exposure to Statins in Dialysis

Wetmore, J.B.; Mahnken, J.D.; Rigler, S.K.; Ellerbeck, E.F.; Mukhopadhyay, P.; Hou, Q.; Shireman, T.I. (Kansas City, Kans.) 